\title{
The Impact of Liquidity, Credit, and Financial Leverage Risks on Financial Performance of Islamic Banks: A Case of Sudanese Banking Sector
}

\author{
Ahmed Nourrein Ahmed Mennawi ${ }^{1}$ \\ ${ }^{1}$ College of Business Studies, Sudan University of Science and Technology, Khartoum, Sudan \\ Correspondence: Ahmed Nourrein Ahmed Mennawi, College of Business Studies, Sudan University of Science \\ and Technology, Khartoum, Sudan. Tel: 249-9121-55537.E-mail: ahmednourrein@gmail.com
}

Received: November 15, 2020 Accepted: December 24, 2020 Online Published: December 26, 2020

\begin{abstract}
This study aims to investigate the impact of liquidity, credit, and financial leverage risks on the financial performance of Islam banks in Sudan during the period of 2008 - 2018. Panel dataset of 143 observations from (13) banks has been used in this study. Two models of ROA and NPM have been constructed using robust random effects estimates for testing the study hypotheses. The independent variables consist of liquidity and credit risks plus the financial Leverage ratio. Credit risk that measured by nonperformance of loan (financing) and provision of loan (financing) loss ratios; while the liquidity risk measured by cash to deposits ratio, liquid assets to total assets ratio and total loan (financing) to total deposits ratio. The financial performance of Islamic banks in Sudan measured by the ratios of return on assets and net profit margin. The results reveal that the credit risk and financial leverage have significant and negative impact on the financial performance of Islamic banks in Sudan, whereas the liquidity risk generally found to be insignificant. Despite that, the liquidity risk in term of liquid assets to total assets ratio provides a significant and positive influence on the financial performance of Sudanese banks. Finally, the importance of this study is that it touches the most significant types of risks that Sudanese Islamic banks face during their operational cycles.
\end{abstract}

Keywords: credit, liquidity, financial leverage, islamic banks, risk management, Sudan

\section{Introduction}

\subsection{Background}

Islamic finance has gained a significant attention at the global arena during recent decades, and especially after its resistance to recent global crisis. Now adays, it is not surprising that Islamic financing system is seen as an alternative to conventional financing system through statistics that underscore a rapid growth of Islamic financial assets and institutions that prohibit to deal with interest rates. Moreover, Islamic finance potentially serves both a growing 1.7 billion Muslim population around the globe and increasingly interested non-Muslim customers. The Islamic finance assets grew by $6 \%$ from 2012 to 2017 to reach US\$2.44 trillion, and expectation of further growth to US $\$ 3.8$ trillion by 2023 . It is worth mentioning that Islamic banks share an approximately of $70 \%$ to $72 \%$ out of Islamic finance assets during 2017 and 2018 (Thomson Reuters, 2018). Furthermore, Islamic banking is seen to be a systemically important in 12 jurisdictions that account for $92 \%$ of the global Islamic banking assets, with the largest ones are Iran, Saudi Arabia, United Arab Emirates, Malaysia, Kuwait and Qatar (IFSB, IFSI Stability Report, 2018).

Like other countries, the banking sector in Sudan expected to play a significant role in promoting various commercial and non-commercial sectors and to create a development in the economy. The emerging of Islamic banking in Sudan began in mid-1980s when formally Faisal Islamic bank started its operations in the country. Subsequently, the Islamic finance industry passed through different stages till it reach to a full-fledged Islamic financial system by 1992. Despite of the noticeable growth in Islamic banks in Sudan, they still considered relatively young comparing with their peers in other Muslimas' jurisdictions. This meanly due to low intermediation, the narrow of equity and foreign exchange markets, and the financial markets and institutions that are still in developing stage (Burger, 2018).

In Islamic economy the banking sector is the dominant financial business that provide financing facilities and participate in economic projects (IFSB, IFSI Stability Report, 2018). However, the activities that run by Islamic 
banking give rise to various types of risks. These risks include common types of risks that similar to what expose to conventional banking industry, such as liquidity, credit, operational, market risks. Additional types of risks that are uniquely associated with Islamic banking industry are equity investment, rate of return and Shariah noncompliance risks (Rosman and Abdul Rahman, 2015). Therefore, Islamic banks are fundamentally required to establish an effective framework for managing the aforementioned risks, to diversify the sources of funds generation and financing projects, and to apply soundness measurements and controls for each types of risks.

Given the nature of Islamic banking activities, this study tends to investigate the impact of credit risk, liquidity risk and financial leverage on Islamic banks in Sudan. The Islamic banks in Sudan are heavily investing in nonparticipatory modes of finance (such as Murabaha, Ijarah, Istisna, Salam) rather than Profit-loss-Sharing modes of finance, as severally reported by central banks of Sudan. This trend is obviously exposing the banks in Sudan to credit and liquidity risks. Moreover, the supervisory body directives the banks to increase their equity capital in order to enhance the banks' capability to absorb any potential risk and to partially protect the depositors' rights.

\subsection{Statement of Problem}

The nature of banking industry - as a business of risks - provides a valid reason to articulate the statement of problem of this study as: "the lack of managing the risks by Islamic banks shall potentially affect their financial performance in unfavorable way". Consequently, the negative impact in managing risks extends to banks' owners, management, funds' depositors and other stakeholders. Therefore, understanding, measuring and controlling risks are paramount important in banking industry in order to achieve its objectives.

\subsection{The Objectives and Scope of the Study}

The main objectives of this study include assessing the impact of various types of risk (mainly liquidity, credit and financial leverage risks) on the financial performance of Sudanese banks, and to shed a light on key risks and financial performance measures in Islamic banks that can assist both decision and policy makers in such industry. Additionally, the study aims to contribute to the concerned empirical literature in the field of risk management and financial performance of Islamic finance industry.

The study is structured as follows: Section two provides a brief literature that focuses on liquidity, credit and financial leverage risk, and the impact of risk management on banks' financial performance. Section three demonstrates the applied methodology that include study dataset, approach, hypotheses, variables characteristics, and model specification. Section four explains the empirical results and discussion of the findings. Finally, section five provides a conclusion, recommendations and limitations of the study.

\section{Literature Review}

Looking into the Islamic banking industry; there are many studies tackled the relationship between risks and bank's financial performance and the impact of such risks on the financial performance of Islamic banks.

In study of a sample of 60 Islamic banks in MENA and Southeastern Asian countries, Ben Jedidia and Hamza (2015) assessed the liquidity risk determinants during the period of 2004 - 2012. In such study, the liquidity risk that measured by two ratios of loan to assets and cash to total assets indicated their positive and significant relation with banks' return of assets (ROA). This result matched the findings of Chowdhury, Zaman and Alam (2019) when the profitability measured by return of assets and rerun on equity (ROE) in their study that included six Islamic Banks in Bangladesh during the period of 2012 - 2016. Furthermore, Islam and Amir (2016) argued that liquidity risk in Islamic banks has a negative and significant impact to their financial performance; regardless these banks are in a surplus or shortage of liquidity. It has been justified that the more liquidity risk exposure leads to enforce the banks to depend highly on internal source of funds (Alzoubi, 2017). Therefore, Islamic banks need to balance their assets and liabilities and to strength their policies and strategies to manage normal liquidity requirement in order to prevent liquidity distress. From other hand, (Ahmed and Khan, 2007); (Ariffin, Archer and Abdel Karim, 2008); (Akhtar, Ali and Sadaqat. 2011); (Islam, Farooq and Ahmed, 2017) and (İncekara and Çetinkaya, 2019) stated that Islamic banks are riskier toward liquidity position than conventional banks, and it imposes a challenge to the management in the context of trading-off between liquidity risk and bank's performance. Contrary, Iqbal (2012) and Gafrej and Abbes (2017) argued that the liquidity position in Islamic banks is better than conventional banks and they have strong cushion against the balance sheet's shocks. In all cases, Muharam (2013) and Effendi and Disman (2017) stated that liquidity risk factors in Islamic and conventional banks are the same, and the differences come from the banks' contractual system, structure of investments portfolio and profitability approach.

For a large number of world's largest deposit-taking banks, Bace (2016) studied the relationship of liquidity and credit risks to banks' profitability during the period of 2014-2015. The linear regression model resulted that the credit risk metrics of nonperforming loan ratio has a negative and significant impact on return of assets (ROA), 
while the equity to assets ratio found to be a positive and significant relation. Additionally, the liquidity risk as measured by loan/advances to deposits ratio has slightly negative relation with banks' profitability. The results indicated that liquidity risk and banks' equity capital have significant implications on banks' performance.

Al Rahahleh, Bhatti and Misman (2019) reviewed the developments of risk management in Islamic banks in Malaysia. The results of such study showed that the expansion of loan financing, quality of the loans, and sufficient capital are the major determinants of credit risk in Islamic banks. The author suggested that any deterioration in financing quality creates a nonperforming loan situation, which is in return forces Islamic banks to allocate more loss provisions. Accordingly, the more nonperforming loan and increasing of loan loss provision can lead to an increase of credit risk that have a negative effect on bank's profitability. Furthermore, Alshatti (2015) examined the effect of credit risk management on financial performance of the Jordanian banks. His study covered a period from 2005 to 2013 for a sample of 13 banks. The banks' financial performance was measured by the ratios of ROA and ROE while the credit risk was measured by the nonperforming loan to total loan, provision of loan loss to loan and the leverage ratios. The study results revealed that the credit risk indicators of nonperforming and provision of loan loss have a significant effect on financial performance of the Jordanian banks. The nonperforming loan showed a positive relationship with banks' financial performance while the provision of loan loss provided a negative impact. Therefore, banks need to manage their credit risk by deeply relay on the diversification of credit risk to decrease the nonperforming amount which will motivate to reduce the amount of provision of loan loss and the to improve the quality of loan and bank's profitability (Ahmadyan, 2018). Furthermore, Misman and Bhatti (2020) examined the critical issues that are related to credit risk in a sample of 72 Islamic banks from nine countries from South East Asian Nations (ASEAN) and Gulf Cooperation Council (GCC) regions during the period of 20002011. The results indicated that quality of loan (financing) has a significant positive effect on credit risk. Also, the large-size Islamic banks have the capacity to lower its credit risk in a comparison with the small-size peers, especially when these banks have access to more equity's capital.

Sarwar (2018) explained that financial leverage ratio, asset turnover and earning per share have a positive relation with ROA. This result provided when the author investigated the core issues of profitability and market size of Islamic banking in Pakistan. The study was based on a sample size of 10 banks during a period from 2007 to 2016. Furthermore, the influence of bank's financial leverage or gearing on bank's ROA has been identified by Khalil. $\mathrm{R}$ and Khalil. M (2017) as insignificant, while it showed a positive impact on the ROE of Islamic banks in Pakistan from 2007 to 2015. Moreover, due to the expansion of Islamic banking, a comparative study conducted by (Issa, 2020) to compare the riskiness between Islamic and conventional banks during the 2008 global crisis. The author measured the overleveraging by the difference between actual and optimal debt by using a sample of 10 conventional and 10 Islamic banks from five countries. The author argued that excess debt can serve as an early indicator of crises and collapse of banks. additionally. The study results provided an evidence that Islamic banks has the capacity to manage their debt better than conventional banks prior the financial crises of 2008, however, they were impacted by the second phase of the crisis that began in 2011. Additionally, the Islamic banks in the GCC countries have been examined by Menacer, Saif-Alyousfi. and Ahmad (2019) to see whether the financial leverage has an impact on financial performance. Their study covered the period from 2005 to 2017 and the data gathered from 25 listed Islamic banks. The results revealed that the financial leverage has a positive and significant impact on financial performance indicators of the Islamic banks in the GCC countries; which measured by ROA, ROE, and Tobin's Q.

In a comparative study between Islamic and conventional banks, Tafri., Hamid., Meera., and Omar (2009) examined the impact of financial risks on bank's profitability. The study covered a period of 10 years (1996 - 2005). Banks' profitability measured by ROA and ROE, while the financial risks include credit risk that measured by provision of loan loss to total asset ratio, interest rate risk, liquidity risks that measured by liquid assets to total liabilities ratio and bank's equity to total assets ratio. The results from panel data regressions revealed that credit risk has a negative and significant impact on both ROA and ROE, while the liquidity risk found to be insignificant on banks' profitability. In addition to that, the results showed that the impact of interest rate risk is significant on ROA only for the conventional banks and it has no impact on Islamic banks' profitability. Regarding the bank capitalization, the results found that bank's capital has a positive and significant impact on the profitability. Also, Al-Rdaydeh, Matar. and Alghzwai (2017) selected a sample of 13 conventional banks and three 3 Islamic banks for the period from 2005 to 2015 to investigate the influence of financial risks on the profitability of Jordanian banks. Panel data regression has been used for testing the study hypotheses. The result of the study indicated that credit risks (in term of loan loss provision ratio) and liquidity risk (in term of loan to deposits ratio) have negative and significant influence on ROA of both types of banks.

Additionally, Amaliah and Hassan (2019) analyzed the relationship between credit risk, liquidity, and capital 
adequacy with Indonesian banks during the period of 2007-2016. The results found that there is a negative and significant impact of nonperforming loan ratio on banks' return of assets and net profit margin, while the liquidity risk (that measured by financing loans to deposits ratio) has a negative and significant impact on ROA only. The capital adequacy is shown to be insignificant toward banks' profitability.

A further study conducted by Abbas, Iqbal and Aziz (2019) on a sample of the 174 banks from 10 countries from Asian countries plus USA to explore the influence of bank capital, liquidity risk, and credit risk on the bank's profitability (that measured by ROA and ROE ratios). The study covered the postcrisis period between from 2011 to 2017. The study results revealed that credit risk when it measured by loan loss provision ratio has a negative and significant influence on the profitability of banks that have large and medium sizes, while the impact is insignificant for in smaller banks. The findings also indicated that liquidity risk (in term of liquid assets to total assets ratio) has a significant impact on banks' profitability with a positive sign in Asian banks, whereas it has negative impact in case of USA banks. The authors claimed that large banks have ability to use their liquid assets in more diversified manners.

Regarding risks management in Sudanese Islamic banks, Ahmed (2016) investigated the interrelationship between the nonperforming loans (finances) and credit risk management, during the period of $2002-2014$. The study results showed that the framework of credit risk management in the Sudanese banks is sufficient and it wasn't a cause of an increase in the nonperforming loans (finances) level. However, the adverse macroeconomic conditions that associated with various economic sectors in Sudan justified the increase of nonperforming loans (finances) as a credit risk issue. Moreover, Elgadi (2016) conducted an empirical study using a panel data estimation models to assess the performance of Islamic banking industry in Sudan during the period from 2005 until 2013. The profitability ratios of return on assets (ROA) and return on equity (ROE) are used to measure the banks' performance. The main results indicated that ROA has a significant and adverse relationship with operation efficiency, credit risk, leverage ratio and profit-loss-sharing mode of financing. Additionally, the results revealed the factors of bank age, size, capitalization and liquidity on banks' profitability.

Another study in the context of credit risk of Sudanese banks is conducted by Mustafa (2019). The study aimed to assess the impact of credit risk on the financial performance of Islamic banks in Sudan during the period from 1995 to 2017. The results found that the credit risk is adversely affects the banks' profitability, and the banks are deeply depending on collateral to mitigate the credit risk. With respect to the impact of liquidity risk management on the financial performance of Sudanese Islamic banks; Mustafa (2020) used panel data analysis to investigate such issue during the period from 1992 to 2018 . The liquidity risk measured by three ratios as liquid assets to total assets, total loan (financing) to total deposits, and current deposits to total deposits ratios. The banks' financial performance is measured by the ratio of ROA. The findings of the study suggested that current deposits to total deposits, total loan (financing) to total deposits ratios have a negative impact on banks' ROA, whereas liquid assets to total assets ratio provides a significant and positive sign. Moreover, Mennawi and Ahmed (2020) found that credit risk has a positive relationship with liquidity risk in Sudanese Islamic banks. Also, their study indicated that banks in Sudan maintain high level of cash buffer and liquid assets for the purpose of meeting the depositors' withdrawals as most of the deposits are in forms of current and saving accounts. Finally, Abdo and Onour (2020) applied a panel data technique in a sample of 25 Sudanese banks in order to examine the liquidity risk determinants. Their study covered the period from 2012 to 2016. The findings of the study indicated that the investment, and profitability are positively significant to liquidity risk; whereas the budget deficit variable is insignificant to liquidity risk. The authors argued that Sudanese Islamic banks are rely on short-term securities (sukuk) as significant proportion in their investment portfolios as a result of the absence of risk-hedging tools

\section{The Study Methodology}

\subsection{Dataset, Sampling and Study Approach}

The researcher uses panel dataset of 11 years (from 2008 to 2018) and a sample of (13) Islamic banks in Sudan. The sample is randomly selected from a population of 37 full-fledged Islamic banks. The study based on a secondary data that has been collected from the audited annual financial statements to construct (6) independent variables that represent liquidity, credit and financial leverage risks; and (2) dependent variables that measure the Islamic banks' financial performance in Sudan. The longitudinal research design with the type of balanced panel data estimate and a quantitative approach have been used in this study. It is worthening to mention that panel data analysis has the advantages of increasing the precision in the estimation for investigating the relationship between variables, it provides more informative data in th study and it improves the efficiency of econometric estimates, and it allows controlling for individual heterogeneity that shall reduce risk of obtaining biased results (Cameron and Trivedi, 2005); and (Brooks, 2008). STATA.16 software has been used in the study to analyse the data, models' 
diagnostic and extract the models' results.

Following null hypotheses (H1 to H6) have been established and tested with confidence level of $95 \%(\alpha=0.05)$ :

H.1: The liquidity risk in form of CADP ratio has a positive and significant impact on financial performance Sudanese banks.

H.2: The liquidity risk in form of LQTA ratio has a positive and significant impact on financial performance Sudanese banks.

H.3: The liquidity risk in form of FIDP ratio has a positive and significant impact on financial performance Sudanese banks.

H.4: The credit risk in form of NPL ratio has a negative and significant impact on financial performance Sudanese banks.

H.5: The credit risk in form of LLP ratio has a negative and significant impact on financial performance Sudanese banks.

H.6: The financial leverage ratio has a negative and significant impact on financial performance Sudanese banks.

\subsection{Variables Characteristics and Model Specification}

\subsubsection{Dependent variables}

Financial Performance: The financial performance of Sudanese banks is measured by the ratios of return on assets (ROA) and net profit margin (NPM). The literature provides an evidence that ROA is widely used to assess the degree of bank's financial performance throughout profitability status. The ROA explains the bank's profitability and how management is efficient in utilizing bank's resources to generate profitability. Such ratio is extensively used as a measurement of banks' financial performance in many studies such as in Ben Jedidia and Hamza (2015); Alshatti (2015); Bace (2016); Elgadi (2016); Al-Rdaydeh, Matar, and Alghzwai (2017); Sarwar (2018); Amaliah and Hassan (2019; Menacer, Saif-Alyousfi, and Ahmad (2019); and Abbas, Iqbal and Aziz (2019). Furthermore, the NPM has chosen in this study as a measure to assess the efficiency of bank's operational results. Such ratio has been used by Amaliah and Hassan (2019)

The financial performance indicators were calculated as follows

ROA $=$ Net Profit (after tax) $/$ Total Assets \%

NPM $=$ Net Profit (after tax) / Total Revenue \%

\subsubsection{Independent Variables}

a) Liquidity Risk: Liquidity risk indicates an unfavorable financial position that results from either shortfall or excess in liquidity position. Banks carefully need to manage such risk in order to meet both planned and unplanned liquidity withdrawal, and to provide necessary level of funds to finance the targeted investment opportunities. Accordingly, this study selected three metrics to measure the magnitude of liquidity risk with reference to previous studies. These measures are.

1) Cash Ratio (CADP) $=$ Cash and Cash Equivalent / Total Deposits \%

This ratio expresses the proportion of total deposits that can be immediately settled to or withdrawals by depositors from available cash and cash equivalent at bank. The higher the ratio the lower the risk of shortage in cash. The ratio can represent the liquidity buffer for meeting the regular withdrawals and operations.

2) Liquid Assets Ratio (LQTA) = Liquid Assets / Total Assets \%

Such ratio indicates the percentage of liquid assets out of total bank's assets. The liquid assets generally include the cash and cash equivalent, reserves at central bank, and short-term marketable securities (such as sukuks). The more liquid assets at bank provides a caution for the liquidity risk. In contrary, the maintaining high level of liquid assets jeopardize the long-term investments decision that it may affect the bank's profitability.

3) Financing out of deposits (FIDP) $=$ Total Financing (Loans) $/$ Total Deposits $\%$

The ratio of FIDP represents the portion that acquired funds from depositors that uses to finance Islamic bank's investments and customers. The high percentage of FIDP ratio indicates that the depositors' funds are largely invested by the bank, therefore, the bank expects to have inadequate liquidity funds to meet depositors' withdrawals, especially if the maturity matching not managed well. From other hands, the bank's profitability is expected to be high in case of large portion of deposits' funds being used to generate earnings, considering that the cost of deposits is relatively low. 
b) Credit risk: The literature shows that non-performing loan (NPL) and provision of loan loss provision (LLP) ratios are the most widely ratios that use to measure the credit risk management and quality of loan in the bank. Since Islamic banks are not dealing with interest rate, the term of financing replaces the term of loan. The NPL is a percentage of gross loans (financing) that represents the doubtful or impairment proportion from investment portfolio of banks. Given that, the management of bank establishes a LLP to absorb the NPL and any potential loss from a doubtful of collection from the bank's counterparty. The more NPL and LLP, the higher credit risks. The calculation of NPL and LLP in Islamic banks as follows:

1) Nonperforming Loan (NPL) = Nonperforming loan (financing) / Gross Loan (Financing)

2) Loan Loss Provision (LLP) = Loan (Financing) Loss Provision / Gross Loan (Financing)

c) Financial Leverage: Financial leverage expresses the relationship between bank's debts and equity funds. Basically, the existing of debts' funds in banks' financial position constitute a core financing source. Nevertheless, a high leverage ratio creates higher business risk for a bank which in turn makes it more difficult to acquire further external capital and tends to increase cost of borrowing from external parties. The simplest way to calculate the bank's financial leverage is by dividing the total debits over total equity. For Islamic banks, the equation is the same as in conventional banks since the investment account holders generally take the characteristics of debts. Therefore, the calculation of financial leverage ratio is shown as follows:

Financial Leverage Ratio $=$ Total Debt $/$ Total Shareholders' Equity

Following table (1) provides summary for the variables that used in this study

Table 1. Variables of the Study

\begin{tabular}{|c|c|c|c|c|}
\hline Type of Variable & Variable Name & Variable Description & Symbol & Expected sign \\
\hline $\begin{array}{l}\text { Dependent } \\
\text { Variable }\end{array}$ & Financial Performance & $\begin{array}{l}\text { Return on Asset } \\
\text { Return on Equity }\end{array}$ & $\begin{array}{l}\text { ROA } \\
\text { ROE }\end{array}$ & \\
\hline $\begin{array}{l}\text { Independent } \\
\text { Independent } \\
\text { Independent } \\
\text { Independent }\end{array}$ & Liquidity Risk & $\begin{array}{l}\text { Cash to Total Deposits } \\
\text { Liquid Assets to Total Assets } \\
\text { Total Financing to Total Deposits } \\
\text { Nonperforming Loan }\end{array}$ & $\begin{array}{l}\text { CADP } \\
\text { LQTA } \\
\text { FIDP } \\
\text { NPL }\end{array}$ & $\begin{array}{l}\text { Positive } \\
\text { Positive } \\
\text { Positive } \\
\text { Negative }\end{array}$ \\
\hline $\begin{array}{l}\text { Independent } \\
\text { Independent }\end{array}$ & Financial Leverage & $\begin{array}{l}\text { Loan Loss Provision } \\
\text { Debt to Equity Ratio }\end{array}$ & $\begin{array}{c}\text { LLP } \\
\text { DTEQ }\end{array}$ & $\begin{array}{l}\text { Negative } \\
\text { Negative }\end{array}$ \\
\hline
\end{tabular}

Source: Author's calculation

\subsection{Model Specification}

The basic framework for the panel data is a regression model of the form:

$$
\mathrm{y}_{\mathrm{it}}=\alpha+\mathrm{X}_{\mathrm{it}} \beta+\mathrm{u}_{\mathrm{it}} \quad i=1, \ldots, \mathrm{N} \quad \mathrm{t}=1, \ldots, \mathrm{T}
$$

Where $y_{i t}$ is the dependent variable; $\alpha$ is the intercept term; $\beta$ is the coefficient of independed variable; and $X_{\text {it }}$ is a $1 \times \mathrm{k}$ vector of observations on the explanatory variables. Whereas, $i$ refers to the entity (cross section), and $\mathrm{t}$ refers to time (time series). The error component of $u_{i t}$ in most of panel data application takes the form of:

$$
u_{i t}=\mu_{i}+v_{i t}
$$

Where, $\mu_{\mathrm{i}}$ denotes to an individual specific effect, and Vit denotes to the 'remainder disturbance' that varies over time series and cross sections.

For the purpose of this study, the models can econometrically be presented as follows:

Model 1: $\quad R O A=\alpha_{0}+\beta 1$ CADPit $+\beta 2$ LQTAit $+\beta 3$ FIDPit $+\beta 4$ NPLit $+\beta 5$ LLPit $+\beta 6$ DTEQit $+\mathrm{u}_{\text {it }}$

Model 2: $\quad \mathrm{NPM}=\alpha_{0}+\beta 1 \mathrm{CADPit}+\beta 2 \mathrm{LQTAit}+\beta 3$ FIDPit $+\beta 4 \mathrm{NPLit}+\beta 5 \mathrm{LLPit}+\beta 6 \mathrm{DTEQit}+\mathrm{u}_{\mathrm{it}}$

Where:

$\alpha_{0}$ : The intercept

$\beta_{1}-\beta_{6}$ : The regression coefficients of independent variables

$i \& t$ : they refer to the banks and the period in the study, respectively 
Uit: the prediction error (residual).

\section{Empirical Results and Discussion}

\subsection{Descriptive Statistics}

Table (2) shows the descriptive statistics that provide general highlights into the characteristics of a studied sample. The standard deviation of each variable does not exceed its respected mean except for the variable NPL that indicates a variation between the sampled banks. Also, the table provides statistics that implies a large variation between the minimum and maximum for most of the variables since the composition of the sample includes different sizes of banks.

Table 2. Descriptive Statistics

\begin{tabular}{ccccc}
\hline Variable & Mean & STD & Min & Max \\
\hline ROA & 3.08 & 2.88 & -7.02 & -49.18 \\
NPM & 33.06 & 19.86 & 6.53 & 68.17 \\
CADP & 34.46 & 16.39 & 10.31 & 96.98 \\
LQTA & 40.31 & 15.96 & 2.85 & 95.38 \\
FIDP & 64.04 & 21.81 & .90 & 138.57 \\
NPL & 5.93 & 3.97 & .23 & 22.38 \\
LLP & 4.23 & 4.48 & 9.56 & 26.37 \\
DTEQ & 679.58 & 438.61 & & 2464 \\
\hline
\end{tabular}

Note. STD: standard deviation; Min: minimum; Mx: maximum

Source: Author's calculation using STATA.16

\subsection{Multicollinearity}

Multicollinearity occurs when an independent variable is highly correlated with one or more independent variables which decrease the ability to predict the dependent measure (Hair, Black, and Anderson. 2014, p.197). Common means for detecting multicollinearity are to calculate the correlation coefficients between any two of the explanatory variables, and the Variance Inflation Factor (VIF) with its corresponding tolerance of the effect that the other independent variables have on the standard error of a regression coefficient. Multicollinearity will not be an issue in case that the correlation coefficients are lower than 0.80 and VIF not exceed 10 (tolerance values of 0.1). Accordingly, following table (3) shows that the largest pairwise correlation coefficient is 0.5805 between LQTA and FIDP. Additionally, the diagnostics test indicates that there is no inflation in the variances of the parameters' estimates as the VIF values lie between 1.08 and $3.38(0.2960<$ tolerance $<0.926)$ which is lower than the suggested thresholds by Hair, Black, and Anderson (2014) (VIF value $\leqslant 5$ with a tolerance value $\geqslant .20$ ). Therefore, we conclude that there is no multicollinearity problem between the independent variables.

Table 3. Multicollinearity Tests of Independent Variables

\begin{tabular}{lllllll|cc}
\hline \multicolumn{7}{c|}{ Pairwise Correlation Coefficient } & \multicolumn{2}{c}{ Variances Inflation Factor } \\
\hline & CADP & LQTA & FIDP & NPL & LLP & DTEQ & VIF & Tolerance \\
CADP & 1.0000 & & & & & & 1.99 & 0.5036 \\
LQTA & 0.4942 & 1.0000 & & & & & 3.38 & 0.2961 \\
FIDP & -0.1461 & -0.5805 & 1.0000 & & & & 1.64 & 0.6099 \\
NPL & 0.2011 & -0.0246 & 0.0264 & 1.0000 & & & 1.31 & 0.7654 \\
LLP & -0.1729 & 0.4455 & 0.2067 & 0.4134 & 1.0000 & & 2.15 & 0.4653 \\
DTEQ & -0.2512 & -0.1528 & 0.0455 & 0.1273 & 0.0113 & 1.0000 & 1.08 & 0.9259 \\
\hline
\end{tabular}

Source: Author's calculation using STATA.16

\subsection{Unit Root Tests}

The presence of a unit root in any time series means that the mean and variance are not independent of time. Therefore, traditional regression techniques based on non-stationary time series produce a spurious regression. 
As the literature suggests that panel-based unit root tests have higher power than unit root test based on individual time series. We applied Levin, Lin and Chu [LLC, (2002)] and Im, Pesaran and Shin [IPS, (2003)] for the stationarity test. Table (4) shows that the series are either stationary at level, I(0) or at first differencing, I(1). Accordingly, we tested the data series for cointegration.

Table 4. The Results of Unit Root Tests

\begin{tabular}{lccc|ccc}
\hline \multirow{2}{*}{ Variable } & \multicolumn{3}{c|}{ Levin, Lin \& Chu } & \multicolumn{3}{c}{ Im, Pesaran and Shin } \\
\cline { 2 - 7 } & Statistic & Prob. & Result & Statistic & Prob. & Result \\
\hline ROA & -4.61880 & 0.0000 & I $(0)$ & -2.56040 & 0.0001 & I (1) \\
NPM & -2.07606 & 0.0189 & I (0) & -2.90913 & 0.0022 & I (1) \\
CADP & -7.64655 & 0.0000 & I (1) & -1.80467 & 0.0356 & I (1) \\
LQTA & -1.86038 & 0.0314 & I (0) & -1.62218 & 0.0396 & I (1) \\
FIDP & -9.05443 & 0.0220 & I (1) & -2.64137 & 0.0041 & I (1) \\
NPL & -7.93642 & 0.0000 & I (0) & -3.43167 & 0.0003 & I (1) \\
LLP & -2.49807 & 0.0062 & I (0) & -3.09556 & 0.0001 & I (1) \\
DTEQ & -6.84509 & 0.0000 & I (0) & -2.02626 & 0.0214 & I (0) \\
\hline
\end{tabular}

Source: Author's calculation using STATA.16

\subsection{Cointegration Tests}

The study used Kao (1999) and Pedroni (1995) tests are most widely used for testing the cointegration. As per table (5), the Modified Phillips-Perron (PP) and Augmented Dickey-Fuller (ADF) provide p-values less than 0.05 for the two models. This result evidences to reject the null hypothesis of no cointegration between the variables, at 0.05 level of significance. Therefore, we can conclude that there will be a long run relationship between the explanatory variables and dependent variable in the two models of the study.

Table 5. the Results of Cointegration Tests

\begin{tabular}{lcc|cc}
\hline Model & \multicolumn{2}{c}{ Model 1 (ROA) } & Model 2 (NPM) \\
\hline \multicolumn{4}{c}{ Pedroni Test for Cointegration } \\
\hline Test & Statistics & P-value & Statistics & P-value \\
Modified Phillips-Perron t & 6.9478 & 0.0000 & 6.7410 & 0.0000 \\
Phillips-Perron t & -4.1524 & 0.0000 & -6.0044 & 0.0000 \\
Augmented Dickey-Fuller t & -71.1857 & 0.0000 & -98.9131 & 0.0000 \\
\hline \multicolumn{5}{c}{ Kao Tests for Cointegration } \\
\hline Test & Statistics & P-value & Statistics & P-value \\
Augmented Dickey-Fuller t & 3.6411 & 0.0001 & 2.3074 & 0.0105 \\
Modified Dickey-Fuller t & -5.1840 & 0.0000 & -4.3774 & 0.0000 \\
Dickey-Fuller t & -5.1532 & 0.0000 & -3.7962 & 0.0001 \\
\hline
\end{tabular}

Source: Author's calculation using STATA.16

\subsection{Residual Diagnostics}

\subsubsection{Heteroskedasticity}

Heteroskedasticity appears when the errors do not have a constant variance. Despite that still there is consistent estimates of the regression coefficients, but these estimates will not be efficient and they will be biased. In such case robust standard errors should be computed for correcting of possible presence of heteroskedasticity (Baltagi, 2005); (Brooks,2008). 
Following table (6) shows the results of Breusch-Pagan test for heteroskedasticity. The results show that probability of Chi square is less than 0.05 for both models, which reject the null hypothesis of homoskedasticity at 0.05 (significance) level. Hence, we conclude that heteroskedasticity is exist in the two models of this study.

Table 6. the Result of Heteroskedasticity Test

\begin{tabular}{lcc}
\hline Model & Chi 2 & Prob. \\
\hline ROA & 35.12 & 0.0000 \\
NPM & 7.63 & 0.0057 \\
\hline
\end{tabular}

Source: Author's calculation using STATA.16

Therefore, an alternative approach to deal with the heteroskedasticity issue in panel data estimates is by clustering the standard error estimates (Brooks, 2014) in order to make the regression efficient and consistent.

\subsubsection{Autocorrelation (Serial Correlation)}

The study carried out Durbin-Watson (D-W) test and Breusch-Godfrey test for identifying if there is autocorrelation between explanatory variables of the models. The D-W test deals with first order autocorrelation of the residuals Ut and Ut-1, whereas Breusch-Godfrey test extends for testing the residuals up to Ut-r, which makes it a general test (Brooks, 2008, p. 148). Following table (7) shows the results from D-W and BreuschGodfrey LM tests for autocorrelation

Table 7. the Results of Autocorrelation Tests

\begin{tabular}{lcc|c}
\hline Test & \multicolumn{2}{c|}{ Breusch-Godfrey } & Durbin-Watson \\
\hline & $\mathrm{Chi}^{2}$ & Prob. & D-W statistics \\
\cline { 2 - 4 } ROA & 0.052 & 0.8190 & 1.960002 \\
NPM & 2.343 & 0.1258 & 1.75175 \\
\hline
\end{tabular}

Source: Author's calculation using STATA.16

The results of Breusch-Godfrey test show that the p-values of Chi squares are larger enough than 0.05 at (significance) level. Additionally, D-W statistics results are 1.96 and 1.75 for models ROA and NPM respectively. Hence the tests concluded that there is no serial correlation in the models' residuals.

\subsection{Model Determination and Regression Analysis}

The researcher follows Park (2011) guidelines of model selection. Formal test of Hausman is carried out to examine whether correlation between an individual effect or/and time effect and regressors is exist or not. The results revealed that the error term is non correlated with any of the regressors in both models of ROA and NPM since the p-value is larger enough than 0.05 level of significance. By this, Random Effects Model (REM) produces valid results than Fixed effects Model (FEM). Furthermore, we used Breusch and Pagan LM test to assess the choice between REM and Pooled OLS. The large Chi squared provides p-values less than 0.05 at (significance) level. By this we can reject the null hypothesis that individual specific or random specific error variance components are zero. Thus, the REM is appropriate than Pooled OLS model. Following table (8) shows the results from Hausman test and Breusch and Pagan LM test

Table 8. Results of Model Determination Tests

\begin{tabular}{|c|c|c|c|c|c|}
\hline Test & \multicolumn{2}{|c|}{ Hausman Test } & Test & \multicolumn{2}{|c|}{ Breusch and Pagan LM } \\
\hline & $\mathrm{Chi}^{2}$ & Prob. & & $\mathrm{Chi}^{2}$ & Prob. \\
\hline ROA & 5.87 & 0.4378 & ROA & 164.04 & 0.0000 \\
\hline NPM & 4.31 & 0.6346 & NPM & 60.14 & 0.0000 \\
\hline
\end{tabular}

Source: Author's calculation using STATA.16 
Accordingly, the random effects model with the option of "robust" has been applied in order to control for heteroskedasticity in models ROA and NPM

Furthermore, table (9) presents the parameters of goodness of fit of the ROA and NPM econometrics models. The values of R2 (coefficient of determination) for the model ROA is 0.63 , whereas for model NPM is 0.60 which provide explanatory power of the models. the joint variations in the explanatory variables of risk management measures $63.7 \%$ of the variation in ROA and $60.4 \%$ variation in NPM, while the remaining percentages refer to the variation due to other factors. The chi squared statistics with their significance $p$-values indicate the goodness of fit for the joint effect of all variables in the models. segma e refers to the standard error of estimates, while rho represents the ratio of individual-specific error variance to the composite error variance in the models. The individual specific error account for $67.4 \%$ and $49.7 \%$ of the entire composite errors in ROA and NPM models, respectively.

Table 9. Model Fitness Parameters

\begin{tabular}{cccccc}
\hline Model & $\mathbf{R}^{\mathbf{2}}$ & Wald chi2 & Prob. & sigma_e (SEE) & rho \\
\hline ROA & 0.6372 & 169.10 & 0.0000 & 1.3019481 & 0.67463701 \\
NPM & 0.6045 & 144.28 & 0.0000 & 11.16938 & 0.49766096 \\
\hline
\end{tabular}

Source: Author's calculation using STATA.16

\subsection{Discussion of the Results}

For testing the study hypotheses, the regression coefficients the two models of ROA and NPM are generated in accordance to robust random effects (GLS) regressions. Table (10) provides the details of each model toward its regression coefficients and statistics.

Table 10. The Regression Coefficients

\begin{tabular}{cccc|cccc}
\hline \multicolumn{4}{c}{ Model 1. ROA } & \multicolumn{3}{c}{ Model 2. NPM } \\
\hline Variable & Coefficient & $\begin{array}{c}\text { Robust Std. } \\
\text { Error }\end{array}$ & Prob. & Variable & Coefficient & $\begin{array}{c}\text { Robust Std. } \\
\text { Error }\end{array}$ & Prob. \\
\hline CADP & -.0076193 & .01403 & 0.587 & CADP & -.164559 & .11321 & 0.146 \\
LQTA & .0904126 & .01879 & 0.000 & LQTA & .7134794 & .15160 & 0.000 \\
FIDP & .000739 & .00958 & 0.939 & FIDP & -.0105921 & .07729 & 0.891 \\
NPL & -.1116645 & .04691 & 0.017 & NPL & -1.150491 & .37848 & 0.002 \\
LLP & -.2074027 & .05339 & 0.000 & LLP & -2.17719 & .43080 & 0.000 \\
DTEQ & -.0030185 & .00038 & 0.000 & DTEQ & -.0149338 & .00312 & 0.000 \\
Constant & 3.247837 & 1.1013 & 0.003 & Constant & 37.20324 & 8.8862 & 0.000 \\
\hline
\end{tabular}

Source: Author's calculation using STATA.16

The results of the hypotheses test are summarized in the following part:

\subsubsection{Liquidly Risk}

The results of regression coefficients in table (10) show that liquidly risk has significant impact on banks' financial performance only when liquidity measures by LQTA ratio. The other liquidity variables (CADP and FIDP) are having insignificant relationship with banks' financial performance. An increase of LQTA ratio by one unit can lead to increase of ROA and NPM ratios by (0.0904) and (0.7134) respectively, when other factors are held constant The positive significant impact of LQTA ratio on the profitability of Sudanese banks can be justified by the philosophy of these banks in maintaining more liquid assets to meet the large portions of depositors' funds that take a form of current account. Accordingly, the banks tend to invest in short-term investment specifically in Islamic Sukuk through the money market in order to achieve two goals. Fist; to assure that there is an available liquid asset to meet the withdrawal demands of depositors in case of liquid cash-shortage. Second; to improve the 
bank's profitability that can be generated from such investment. The positive impact of liquidity risk on banks' financial performance has also been evidenced by previous studies of Abbas, Iqbal and Aziz (2019); and Mustafa (2020). However, in contrary to Ben Jedidia and Hamza (2015); and Chowdhury, Zaman and Alam (2019) findings.

\subsubsection{Credit Risk}

The two proxies (NPL and LLP) of credit risk show a negative and significant impact on the financial performance of Sudanese banks, as shown in table (10). This implies that an increase of nonperforming ratio by one unit will reduce the ROA by (0.1116) and NPM by (1.1504) units, respectively, when all other variables are constant. Additionally, the increase of loan (financing) loss provision ratio by one unit leads to decrease in ROA and NPM by (0.2074) and (2.1771) units, respectively. The adverse relationship between credit risk and banks' financial performance is an expected result. As the failure of banks' counterparties to settle their loan (financing) will increase the operational costs and probably reduce the liquidity of banks. The result of adverse impact of credit risk on banks' financial performance that measured in form of profitability is in agreement with previous studies of Tafri, et al., (2009); Bace (2016); Elgadi (2016); Al-Rdaydeh, Matar, and Alghzwai (2017); Mustafa (2019); Amaliah and Hassan (2019); and Abbas, Iqbal and Aziz (2019).

\subsubsection{Financial Leverage}

The regression coefficients results indicate that the financial leverage of Sudanese banks has a negative and significant impact on their financial performance. This implies that the more relying on external funds to finance the banks' assets will increase the risk; which in return it adversely affects the bank's profitability. Moreover, the higher the financial leverage or gearing ratio motivate the depositors to claim a premium on addition risk, that it drives to increase the cost of external finance that tends to reduce banks' profitability. The results that shown in table (10) provide that a one unit increase of financial leverage will reduce the return on assets ratio by $(0.0030)$ and the net profit margin by (0.0149), assuming all other factors are constant. This finding is matched the study of Elgadi (2016), however in an opposite view of Sarwar (2018); Menacer, Saif-Alyousfi, and Ahmad (2019) studies.

To sum up, we can conclude that the regression coefficients provide evidences to not reject the hypotheses $\mathrm{H} 2, \mathrm{H} 4$, $\mathrm{H} 5$, and $\mathrm{H} 6$, whereas the study rejects $\mathrm{H} 1$ and $\mathrm{H} 3$.

\section{Conclusion}

This study aims to investigate the impact of liquidity risk, credit risk and financial leverage on the financial performance of Sudanese banks during the period from 2008 to 2018. A secondary dataset from 13 banks has been collected and analysed using panel data estimates throughout two models, namely return on assets and net profit margin. The econometric diagnostics provide evidences that robust random effects (generalized least squares GLS) regression is the appropriate estimation to be applied for testing the hypotheses of the study. The regressions results revel that credit risk measures and financial leverage are highly significant with an adverse impact on the financial performance of Sudanese banks. Additionally, two out of three liquidity risk metrics provide insignificant impact on the financial performance of Sudanese banks.

The researcher recommends that Sudanese banks have to manage their credit risk by relaying on the diversification of their investment portfolio, and effective credit policy in addition to appropriate types of collaterals. Additionally, banks are encouraged to improve their liquidity management tools, and attracting more stable funds from capital (internal funds) in order to promote the long-term investments position. Furthermore, Sudanese banks are recommended to strategically train and develop their staff toward the risks' identification, measurement and control. All these are expected to enhance the earning power and to improve the soundness of financial performance of Sudanese banks.

The study provides insights for understanding and identifying risks factors that affect the financial performance in a full-fledged Islamic banking system, such as in Sudan. This can support the decision makers and interested parties regarding risk management and policies in Islamic banking.

Moreover, the study limitations lie on the coverage period from 2008 to 2018, the sample is limited to 13 banks from a population of 37 banks, the use of historical data, and variables in the study are not covere all types of risks that may affect Islamic banks.

\section{References}

Abbas. F., Iqbal. S., \& Aziz. B. (2019). The Impact of Bank Capital, Bank liquidity and Credit Risk on Profitability in Postcrisis Period: A Comparative Study of US and Asia. Cogent Economics \& Finance, 7(1), 1-18. https://doi.org/10.1080/23322039.2019.1605683

Abdo. M. M., \& Onour. I. A. (2020). Liquidity Risk Management in Full-fledged Islamic Banking system. 
Management and Economics Research Journal, 6(2), 1-7. https://doi.org/10.18639/MERJ.2020.990012

Ahmadyan, A. (2018). Measuring Credit Risk Management and its Impact on Bank Performance in Iran. Marketing and Branding Research, 5(2018), 168-183. Retrieved from https://ssrn.com/abstract=3347026

Ahmed E. A. Y. (2016). Credit Risk Management in Islamic Banks: With Special Reference to Non-performing Finance in the Sudanese Banks, 2002-2014. A Thesis Submitted to the University of Gezira in Fulfilment of the Requirements for the Award of the Degree of Doctor of Philosophy in Islamic Banking and Finance. The Institute for Islamization of Knowledge. February.2016 (unpublished)

Ahmed, H., \& Khan. T. (2007). Risk Management in Islamic Banking. In Hassan. M. Kabir \& Lewis. K. Mervyn (Eds.), Handbook of Islamic Banking. Edward Elgar Publishing: UK.

Akhtar. M., Ali. K., \& Sadaqat. S. (2011). Liquidity Risk Management: A Comparative Study Between Conventional and Islamic Banks of Pakistan. Interdisciplinary Journal of Research in Business, 1(1), 35-44.

Al Rahahleh, N., Bhatti. M. I., \& Misman. F. N. (2019). Developments in Risk Management in Islamic Finance: A Review. Journal of Risk and Financial Management, 12(37), 1-22. DOI: http://dx.doi.org/10.3390/jrfm12010037

Al-Rdaydeh, M., Matar, A., \& Alghzwai. O. (2017). Analyzing the Effect of Credit and Liquidity Risks on Profitability of Conventional and Islamic Jordanian", International Journal of Academic Research in Business and Social Sciences, 7(12), 1145-1155. http://dx.doi.org/10.6007/IJARBSS/v7-i12/3745

Alshatti. A. S. (2015). The effect of credit risk management on financial performance of the Jordanian commercial banks". Investment Management and Financial Innovations, 12(1), 338-345. Retrieved from www.businessperspectives.org

Alzoubi. T. (2017). Determinants of liquidity risk in Islamic banks. Journal of Banks and Bank Systems, 12(3), 142-147. http://dx.doi.org/10.21511/bbs.12(3).2017.10

Amaliah. S. R., \& Hassan. H. H. (2019). The Relationship between Bank's Credit Risk, Liquidity, and Capital Adequacy towards its Profitability in Indonesia. International Journal of Recent Technology and Engineering (IJRTE), 7(5S), 225-237

Ariffin. N. M., Archer. S., \& Abdel Karim, R. A. (2008). Risks in Islamic banks: Evidence from empirical research”. Journal of Banking Regulation, 10(2),153-163. http://dx.doi.org/10.1057/jbr.2008.27

Bace. E. (2016). Bank Profitability: Liquidity, Capital and Asset Quality. Journal of Risk Management in Financial Institutions, 9(4), 327-331.

Baltagi. B. H. (2005). Econometric Analysis of Panel Data”, (3rd edition), John Wiley \&Sons Ltd, Chichester, West Sussex. England. Retrieved from www.wileyeurope.com

Ben Jedidia, K., \& Hamza. H. (2015). Determinants of Liquidity Risk in Islamic Banks: A Panel Study. EJBMSpecial Issue: Islamic Management and Business, 7(16), 137-146.

Breusch T. S., \& Pagan A. R. (1979). A Simple Test for Heteroscedasticity and Random Coefficient Variation. Journal of Econometrica, 47(5), 1287-1294. Published by: The Econometric Society Stable. Retrieved from http://www.jstor.com/stable/1911963

Brooks. C. (2008). Introductory Econometrics for Finance (2nd ed). Cambridge University Press. New York. USA. Retrieved from www.cambridge.org/9780521873062

Brooks. C. (2014). Introductory Econometrics for Finance (3rd ed). Cambridge University Press, New York. USA. Retrieved from www.cambridge.org/9781107661455

Burger, J. (2018). The Financial Services Sector in Sudan”, How We Made it in Africa. Africa Business Insight. Retrieved from https://www.howwemadeitinafrica.com/the-financial-services-sector-in-sudan/61452

Cameron. A. C., \& Trivedi. P. K. (2005). Microeconometrics Methods and Applications. Cambridge University Press, New York. USA. Retrieved from www.cambridge.org/9780521848053

Chowdhury M. M., Zaman. S., \& Alam. M. A. (2019). Liquidity Risk Management of Islamic Banks in Bangladesh. International Journal of Business and Technopreneurship, 9(1), 37-48

Effendi K. A., \& Disman. D. (2017). Liquidity Risk: Comparison between Islamic and Conventional Banking. European Research Studies Journal, XX(2A), 308-318.

Elgadi, E. M. (2016). Assessing the Financial Performance of Islamic Banking: The case of Sudanese banks. A 
Thesis Submitted in Partial Fulfilment of the Requirements of the University of East London for the Degree of PhD, School of Business and Law. April.2016 (Unpublished).

Gafrej, O., \& Abbes, M. B. (2017). Liquidity Determinants of Islamic and Conventional Banks" Journal of Islamic Banking and Finance - Global Perspective of Islamic Finance, 34(2), 44-61.

Hair, J. J. F., Black, W. C., B. B. J., \& Anderson, R. E. (2014). Multivariate Data Analysis. (7th edition) Pearson Education Limited, Edinburgh. UK. Retrieved from www.pearsoned.co.uk

Im, K. S., Pesaran, M. H., \& Shin, Y. (2003). Testing for unit roots in heterogeneous panels. Journal of Econometrics, 115(1), 53-74. http://dx.doi.org/10.1016/s0304-4076(03)00092-7

İncekara, A., \& Çetinkaya, H. (2019). Liquidity Risk Management: A Comparative Analysis of Panel Data Between Islamic and Conventional Banking in Turkey. Procedia Computer Science, 158(2019), 955-963. http://dx.doi.org/10.1016/j.procs.2019.09.136

Iqbal. A. (2012). Liquidity Risk Management: A Comparative Study between Conventional and Islamic of Pakistan. Global Journal of Management and Business Research, 12(5), 54-64.

Ishtiaq, M. (2015). Risk Management in Banks: Determination of Practices and Relationship with Performance. A Thesis Submitted in Partial Fulfilment of the Requirements for the Degree of PhD. (March.2015), University of Bedfordshire. UK.

Islam, A., \& Amir, S. (2016). Liquidity Problems in Islamic Banks; Reasons, Impacts and Solutions. COMSATS Journal of Islamic Finance, 1(2016), 1-9.

Islam, A., Farooq, M., \& Ahmad, A. (2017). Factors Affecting Liquidity Position of Islamic Banks. City University Research Journal, Special Issue: AIC, Malaysia (2017), 27-36.

Islamic Financial Services Board - IFSB. (2018). Islamic Financial Services Industry Stability Report (2018). Kuala Lumpur, Malaysia. Rederived from https://www.ifsb.org

Issa, S. (2020). Life after Debt: The Effects of Overleveraging on Conventional and Islamic Banks. Journal of Risk Financial Managemen, 13(137), 1-44. http://dx.doi.org/10.3390/jrfm13060137

Kao, S. (1999). Spurious Regression and Residual-based Tests for Cointegration in Panel data. Journal of Econometrics, 90(1999), 1-44.

Khalil, R., \& Khalil, M. A (2017). Does Bank Size and Operational Efficiency Matters? An Impact of Financial Gearing and Asset Management on Islamic Bank's Performance in Pakistan. Journal of Accounting and Finance in Emerging Economies, 3(1), 63-77.

Levin, A., Lin, C., \& Chu, C. S. J. (2002). Unit root tests in panel data: asymptotic and finite-sample properties. Journal of Econometrics, 108(2002), 1-24. https://doi.org/10.1016/S0304-4076(01)00098-7

Menacer, A., Saif-Alyousfi, A. Y. H., \& Ahmad, N. H. (2019). The Effect of Financial Leverage on the Islamic Banks' Performance in the Gulf Cooperation Council (GCC) Countries. International Journal of Financial Research, 11(1), 13-24. https://doi.org/10.5430/ijfr.v11n1p13

Mennawi, A. N. A., \& Ahmed, A. A (2020). The Determinants of Liquidity Risk in Islamic Banks: A Case of Sudanese Banking Sector. International Journal of Islamic Banking and Finance Research, 4(1), 38-49. Rederived from www.cribfb.com/journal/index.php/ijibfr

Misman, F. N., \& Bhatti, M. I. (2020). The Determinants of Credit Risk: An Evidence from ASEAN and GCC Islamic Banks. Journal of Risk and Financial Management, 13(89), 1-22. http://dx.doi.org/10.3390/jrfm13050089

Muharam. H. (2013). The Influence of Fundamental Factors to Liquidity Risk on Banking Industry: Comparative Study between Islamic Bank and Conventional Bank in Indonesia" UNISSULA, SEMARANG, (October 12, 2013). Conference in Business, Accounting and Management, 1(2), 359-368. http://dx.doi.org/10.2139/ssrn.2339598

Mustafa, O. A. O. (2019). Assessment of the Financial Performance of Islamic Commercial Banks in Sudan under Credit Risk and Inflation Pressures (1995-2017). Journal of Islamic Banking and Finance, 7(1), 14-26. https://doi.org/10.15640/jibf.v7n1a2

Mustafa, O. A. O. (2020). Impact of liquidity shortage risk on financial performance of Sudanese Islamic banks. International Journal of Islamic Economics and Finance, 3(2), 251-280. https://doi.org/10.18196/ijief.3229

Park. H. M. (2011). Practical Guides to Panel Data Modeling: A Step-by-step Analysis Using Stata. Tutorial 
Working Paper. Graduate School of International Relations, International University of Japan. Niigata. Japan. Rederived from http://www.iuj.ac.jp/faculty/kucc625

Pedroni, P. (1995). Panel Cointegration; Asymptotic and Finite Sample Prosperities of Pooled Time Series Tests with An Application of PPP Hypothesis. Revised Working Paper. Presented at the North American and European Econometric Society Meetings. Quebec and Maastricht Respectively During the Summer of 1994. Rederived from https://web.williams.edu/Economics/pedroni/WP-95-13.pdf

Rosman, R., \& Abdul Rahman, A. (2015). The practice of IFSB guiding principles of risk management by Islamic banks International evidence. Journal of Islamic Accounting and Business Research, 6(2), $150-172$. https://doi.org/10.1108/JIABR-09-2012-0058

Sarwar, M. F. (2018). Impact of Profitability on Market Size of Islamic Banking of Pakistan. International Journal of Accounting Research, 6(2.181), 1-5.

Tafri, F. H., Hamid, Z., Meera, A. K. M., \& Omar, M. A. (2009). The Impact of Financial Risks on Profitability of Malaysian Commercial Banks: 1996-2005. World Academy of Science, Engineering and Technology, 30(2009), 1668-1682.

Thomson Reuters (2018). Islamic Finance Development Report 2018 - Building Momentum Report. Rederived from https://ceif.iba.edu.pk/pdf/Reuters-Islamic-finance-development-report2018.pdf

\section{Copyrights}

Copyright for this article is retained by the author(s), with first publication rights granted to the journal.

This is an open-access article distributed under the terms and conditions of the Creative Commons Attribution license (http://creativecommons.org/licenses/by/4.0/). 